Migration Studies - Review of Polish Diaspora nr 2 (176)/2020, http://www.ejournals.eu/Studia-Migracyjne/ DOI: $10.4467 / 25444972$ SMPP.20.013.12329

\title{
Detencja cudzoziemców jako temat badawczy i wyzwanie metodologiczne
}

\author{
JACEK SCHMIDT ${ }^{1}$ \\ ORCID: 0000-0002-4074-5942 \\ Uniwersytet im. Adama Mickiewicza w Poznaniu
}

\begin{abstract}
Tekst zawiera prezentację koncepcji i założeń metodologicznych (strategii badawczych) projektu "Organizacja przestrzeni w polskich ośrodkach detencyjnych dla cudzoziemców”. Jest to pionierskie przedsięwzięcie badawcze realizowane w instytucji totalnej, która do tej pory pozostawała poza oglądem przedstawicieli nauk społecznych. Roczne badania zespołowe, które przeprowadzono we wszystkich sześciu strzeżonych ośrodków dla cudzoziemców w Polsce miały charakter interdyscyplinarny, wymagały opracowania autorskiej, a zarazem eklektycznej koncepcji badania kultury organizacyjnej instytucji totalnej, odwołującej się do różnych inspiracji teoretycznych (proksemika, kinezyka, interakcjonizm symboliczny, teoria morfogenezy, koncepcja "patron-klient”, koncepcja ekonomii moralności i in.).
\end{abstract}

Słowa kluczowe: instytucja totalna, detencja cudzoziemców, strategie badawcze, interdyscyplinarność

\section{Detention of Foreigners as a Research Topic and Methodological Challenge}

The paper presents the conceptual and methodological assumptions (research strategies) regarding the project "Space organisation in Polish detention centres for foreigners". This pioneer research project studies detention centres as a total institution, which so far was outside the area of academic interest. An interdisciplinary, one-year group research project in all six guarded centres for foreigners in Poland involved an original, eclectic concept of studying the organisational culture of total institutions. This concept referred to various theoretical inspirations, such as proxemics, kinesics, symbolic interactionism, morphogenesis theory, the model of patron-client relations, the concept of morality economics, etc.

Keywords: total institutions, detention of foreigners, research strategies, interdisciplinarity

1 Kontakt: jschmidt@amu.edu.pl 
Celem tego tekstu jest przybliżenie czytelnikom koncepcji i założeń metodologicznych projektu badawczego „Organizacja przestrzeni w polskich ośrodkach detencyjnych dla cudzoziemców"2. W ramach zainteresowań badawczych autorów projektu znalazły się następujące obszary tematyczne: (1) uwarunkowania formalno-prawne oddziałujące na specyfikę organizacji przestrzeni fizycznej i społecznej instytucji detencyjnej, (2) sposoby „odczytywania” przestrzeni społecznej ośrodków detencyjnych przez wszystkich aktorów w nich funkcjonujących, (3) konsekwencje percepcji przestrzeni i pojawiających się w niej praktyk społecznych dla funkcjonowania kultury detencyjnej i jej uczestników. Faza empiryczna projektu zakończyła się latem 2019 roku, a pod koniec 2020 roku i w kolejnych kilkunastu miesiącach należy spodziewać się całej serii publikacji metodologicznych i wynikowych. Z tego względu przedłożone poniżej informacje można potraktować jako ich zwiastun, wstępną formę popularyzacji naszych dociekań badawczych ${ }^{3}$.

Detencja cudzoziemców polega na czasowym pozbawieniu ich wolności poprzez umieszczenie w odizolowanym obiekcie zarządzanym przez urząd lub służby zajmujące się imigracją, w celu realizacji procedur migracyjnych - przede wszystkim zabezpieczenia postępowania powrotowego ${ }^{4}$. O umieszczeniu w takim obiekcie decyduje sąd na wniosek instytucji nim administrującym. Detencji poddawani są cudzoziemcy w celu ustalenia lub weryfikacji ich tożsamości, zapobieżeniu nadużyciom postępowania w związku z udzieleniem ochrony międzynarodowej, zabezpieczeniu zagrożenia dla bezpieczeństwa, zdrowia, życia lub własności innych osób, ochrony obronności lub bezpieczeństwa państwa albo ochrony bezpieczeństwa i porządku publicznego ${ }^{5}$. Oznacza to, że umieszczane tam są zarówno osoby, które nielegalnie przekroczyły granicę, jak i imigranci ubiegający się o różne formy ochrony międzynarodowej.

W kilku ostatnich dekadach mamy do czynienia z bardzo znaczącym wzrostem skali i zakresu stosowania detencji wobec cudzoziemców ${ }^{6}$. Tylko w latach 2000-2012 liczba

2 Projekt realizowany jest przez zespół, którego trzon stanowią pracownicy Uniwersytetów Jagiellońskiego i Adama Mickiewicza w Poznaniu. W związku z niespodziewanym uzyskaniem czasowej zgody na przeprowadzenie badań terenowych w ośrodkach dla cudzoziemców nie było możliwe ubieganie się o finansowanie tego przedsięwzięcia w trybie konkursowym (np. w NCN). W tej sytuacji jedynym rozwiązaniem było pozyskanie dofinansowania ze strony instytucji macierzystych wykonawców i Ministerstwa Nauki i Szkolnictwa Wyższego (dotacja statutowa) oraz wkład własny uczestników projektu.

3 Pierwszym z tekstów będzie monografia poświęcona metodologicznym aspektom przedmiotowego projektu, D. Niedźwiedzki, J. Schmidt, (2020), Detencja cudzoziemców w Polsce Perspektywa teoretyczno-metodologiczna, która pojawi się także w wersji anglojęzycznej.

4 S.J. Silverman, E. Massa (2012), Why Immigration Detention is Unique. "Population, Space and Place", 18: 677-686; T. Sieniow (2016), Stosowanie alternatyw do detencji cudzoziemców w Polsce w latach 2014-2015 Raport z monitoringu. Lublin, s. 15-16.

${ }^{5}$ Ustawa o Cudzoziemcach (2013, art. 398s) przywołuje cztery przesłanki, na mocy, których umieszcza się cudzoziemca w strzeżonym ośrodku, zob. https://www.lexlege.pl/ustawa-o-cudzoziemcach/art-398a/ [data dostępu:15.10.2016]

${ }^{6}$ Np. D. Wilsher (2014), Immigration Detention. Law, History, Politics. Cambridge, s. ix; N. Labanca, M. Ceccorulli (2014), Introduction, in: Ceccorulli M., Labanca N. (red.). The EU, Migration and the Politics of Administrative Detention. London and New York, s. 3. 


\section{SM̂PP}

ośrodków detencyjnych we wszystkich 28 państwach Unii Europejskiej i 16 państwach ościennych wzrosła z 324 do 473. W samym 2012 roku detencją objęto 570660 imigrantów, a 252785 z nich poddano procedurom powrotowym lub deportowano7.

Detencja jest tylko relatywnie małą częścią bardzo złożonego procesu zarządzania międzynarodowymi migracjami jednak budzącą wiele kontrowersji w środowisku prawników, stanowczy sprzeciw obrońców praw człowieka, będącą spektakularnym tematem dla mediów w przypadku pojawiania się sytuacji „kryzysowych” (np. protesty pensjonariuszy), akcentowaną przez polityków jako niezbędne narzędzie do realizacji suwerennej polityki państwa w obszarze bezpieczeństwa ${ }^{8}$. Jednocześnie jako temat „wstydliwy" jest owiana aurą tajemniczości, hermetyczna i niedostępna do oglądu zewnętrznego obserwatora, w tym przedstawicieli nauki. W związku z tym większość tekstów naukowych poświęconych przymusowemu umieszczaniu cudzoziemców w ośrodkach strzeżonych stanowią opracowania prawników, których zainteresowania badawcze są często ukierunkowane na kontrolę przestrzegania międzynarodowych oraz państwowych norm prawnych regulujących kwestie detencyjne, w tym ich interpretowanie, a w ślad za tym stosowanie przez administrację z konsekwencjami dla imigrantów ${ }^{9}$. Zarówno w Polsce, jak i innych krajach europejskich nie przeprowadzono dotąd kompleksowych badań terenowych w placówkach detencyjnych z udziałem antropologów i socjologów ${ }^{10}$. Ten deficyt wiedzy o funkcjonowaniu ośrodków detencyjnych dla cudzoziemców tylko w pewnym zakresie rekompensują raporty z monitoringów prowadzonych przez organizacje pozarządowe ${ }^{11}$, autonomiczne

7 Migreurop (2014), Detention of Migrants. The favourite means of migration "management”. "Migreurop brief", $n r$ 2, s. 2. http://www.migreurop.org/IMG/pdf/Note_de_MIGREUROP_detention_EN_Web. pdf [data dostępu: 15.12.2019]

${ }^{8}$ W projekcie nowej polityki migracyjnej RP, który ujawniono w 2019 roku, wyeksponowano m.in. kwestie związane z szeroko rozumianą sekurytyzacją, potrzebę poszerzenia kompetencji Straży Granicznej, w tym zwiększenia roli detencji jako narzędzia neutralizującego zagrożenia związane z migracjami, zob. Założenia Polityki Migracyjnej Polski. (2019). Redakcja: Zespół do spraw Migracji. Departament Analiz i Polityki Migracyjnej MSWiA. https://interwencjaprawna.pl/wp-content/uploads/2019/06/Polityka-migracyjna-Polski-wersja-ostateczna.pdf [data dostępu: 15.12.2019]

Zapisane tam założenia zostały ostro skrytykowane przez środowisko badaczy migracji - Stanowisko Komitetu Badań nad Migracjami PAN w sprawie dokumentu "Polityka migracyjna Polski” (10 czerwca 2019 r., 70 s.) http://www.kbnm.pan.pl/images/Stanowisko_KBnM_Polska_polityka_migracyjna_03072019. pdf [data dostępu: 15.12.2019]

${ }^{9}$ Np. B. Ryan, V. Mitsilegas (red.) (2010, Extrateritorial Imigration Control. Legal Challenges, Leiden-Boston; Sieniow, op. cit.; P. Jankowska (2017), Detencja cudzoziemców w Polsce - granice konfliktu interesów, "Internetowy Przegląd Prawniczy TBSP UJ", nr 4, s. 152-162.

10 Pewien wyłom w tym zakresie stanowi monografia M. Bosworth (2014). Inside Migration Detention, Oxford, w której zaprezentowano wyniki blisko dwuletnich badań terenowych przeprowadzonych we wszystkich ośrodkach detencyjnych w Wielkiej Brytanii. Wybiórcze informacje na temat detencji cudzoziemców w innych państwach unijnych, a także teoretyczne ujęcia przedmiotowego zjawiska można znaleźć w pracach zbiorowych, np. M.J. Flynn i M.B. Flynn (red.) (2017), Challenging Immigration Detention: Academics, Activists and Policy-makers, Cheltenham.

11 Np. W. Klaus, K. Rusiłowicz (red.) (2012), Migracja to nie zbrodnia. Raport z monitoringu strzeżonych ośrodków dla cudzoziemców, Warszawa. https://interwencjaprawna.pl/wp-content/uploads/mo- 
instytucje państwowe ${ }^{12}$, czy podmioty międzynarodowe, takie jak np. Urząd Wysokiego Komisarza ONZ ds. Uchodźców. Z powyższych względów interesujące nas zjawisko jest mało rozpoznane, a w kontekście polskim można je wręcz zakwalifikować jako "białą plamę" w wiedzy naukowej, stąd wymagające opracowania autorskiej strategii prowadzenia badań.

Od 2008 roku Straż Graniczna RP jest instytucją zarządzającą detencją cudzoziemców w obecnej strukturze administracyjnej ${ }^{13}$. Organem SG sprawującym nadzór nad sześcioma strzeżonymi ośrodkami dla cudzoziemców (oraz dwoma aresztami) jest Zarząd ds. Cudzoziemców w Komendzie Głównej SG. Ośrodki te funkcjonują w różnych lokalnych strukturach organizacyjnych SG, mają różne profile (męski, rodzinny, mieszany), mogą pomieścić łącznie 573 cudzoziemców: 130 - Biała Podlaska, 122 - Białystok, 120 - Kętrzyn, 103 - Przemyśl, 50 - Lesznowola, 48 - Krosno Odrzańskie ${ }^{14}$. Sektor detencji (mowa tu o strzeżonych ośrodkach) dysponuje około 700 etatami, jednak w praktyce część z nich jest nieobsadzona ${ }^{15}$. Zdecydowana większość z nich przypada na zespoły/sekcje ochrony, które pracują w systemie zmianowym. Ponadto prace na rzecz ośrodków świadczą podmioty zewnętrzne (catering, służba zdrowia, firmy sprzątające). W literaturze przedmiotu często pojawia się stwierdzenie, iż pomimo funkcjonowania w ramach tych samych reguł i standardów prawnych, każdy ośrodek detencyjny różni się od pozostałych, stanowi zamknięty mikroświat ${ }^{16}$. Uwaga ta dotyczy zarówno różnic na poziomie międzynarodowym, jak i w kontekście jednego państwa. Nasze rozpoznanie w pełni potwierdza taki stan rzeczy.

Na potrzeby badania detencji liderzy projektu powołali zespół, w skład którego weszli antropolodzy społeczno-kulturowi, socjolog, prawnik, psycholog i przedstawiciel nauk o bezpieczeństwie. Działania zespołu nie ograniczały się tylko do wspólnego budowania programu interdyscyplinarności - definiowania i uzasadniania powiązań między poszczególnymi dyscyplinami na drodze tworzenia ogólnego aparatu

nitoring_osrodkow_strzezonych 2012.pdf; [data dostępu: 15.12.2019], J. Białas, W. Klaus (red.) (2014), Wciąż za kratami. Raport z monitoringu strzeżonych ośrodków dla cudzoziemców przeprowadzony przez Helsińską Fundację Praw Człowieka oraz Stowarzyszenie Interwencji Prawnej, Warszawa. https://interwencjaprawna.pl/wp-content/uploads/wciaz-za-kratami.pdf [data dostępu: 15.12.2019]

12 Mowa tu przede wszystkim o Rzeczniku Praw Obywatelskich, który od 2008 roku koordynuje zadania Krajowego Mechanizmu Prewencji Tortur, w tym wizytacje we wszystkich ośrodkach detencyjnych wyciągi z raportów po wizytacjach można znaleźć na stronie https://www.rpo.gov.pl.

13 N. Rafalik (2012), Cudzoziemcy ubiegający się o nadanie statusu uchodźcy w Polsce - teoria a rzeczywistość (praktyka) (stan prawny na dzień 31 grudnia 2011 r.), CMR Working Papers, No. 55/113, s. 52. Wcześniej, w latach 1996-2007, istniał tylko jeden ośrodek strzeżony dla cudzoziemców - w Lesznowoli, który był zarządzany przez Policję. Straż Graniczna w tym okresie, podobnie jak Policja, administrowała aresztami w celu wydalenia.

14 Dane odnoszące się do pierwszego kwartału 2019 r. Liczba miejsc dla cudzoziemców, którymi dysponuje SG zmienia się w związku z prowadzonymi remontami (np. ośrodek w Białej Podlaskiej jest nieczynny w 2020 roku).

${ }^{15}$ W niektórych lokalizacjach liczba wakatów sięga nawet 20\% - na podstawie kompletu dokumentów dotyczących struktury etatowej w każdym SOdC (stan na okres wiosenny 2019 r.).

16 Np. Labanca, Ceccorulli, op. cit., s. 9-10. 


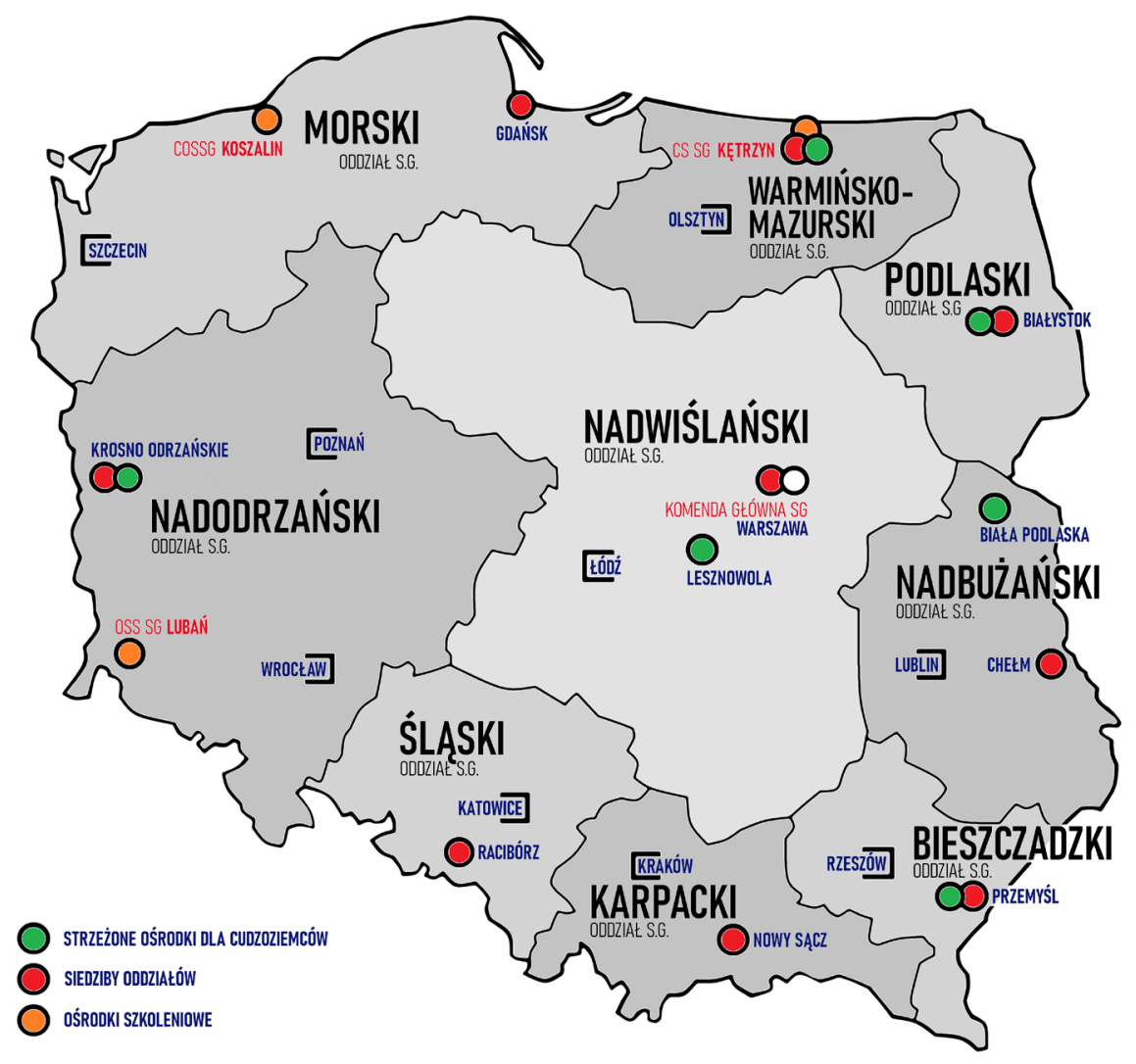

pojęciowego oraz pakietów niesprzecznych podejść teoretycznych i założeń metodologicznych, czyli wertykalnej struktury interdyscyplinarności. Tym, co okazało się równie istotne, było wytworzenie tzw. sytuacji interdyscyplinarności. Wyraża się ona w kreowaniu przestrzeni społecznej, w ramach której dochodzi do regularnej, wręcz intensywnej współpracy na każdym etapie postępowania, w oparciu o zasady i standardy akceptowalne na gruncie każdej z nauk reprezentowanych w przedsięwzięciu badawczym. W ten sposób spełniany jest postulat horyzontalnej struktury interdyscyplinarności ${ }^{17}$. Warto też w tym miejscu zaznaczyć, że każdy badacz/badaczka, niezależnie od profilu indywidualnych zainteresowań zgłębianym tematem, w identycznym lub bardzo zbliżonym stopniu uczestniczył/a we wszystkich etapach postępowania badawczego, ze szczególnym uwzględnieniem pakietu prac związanych z pobytem w terenie.

17 J. Kurczewska (2014), Autorytet i interdyscyplinarność, w: Kurczewska J., Lejzerowicz M. (red.), Głosy w sprawie interdyscyplinarności. Socjologowie, filozofowie $i$ inni o pojęciach, podejściach i swych doświadczeniach, Warszawa, s. 276; J. Brudzińska (2014), Horyzontalna a wertykalna struktura interdyscyplinarności. Spojrzenie fenomenologiczne, w: Kurczewska J., Lejzerowicz M. (red.), Głosy w sprawie interdyscyplinarności..., op. cit., Warszawa, s. 252-253. 
Opisywany projekt wpisuje się w metaforyczną ideę interdyscyplinarności określaną jako „budowanie mostów” (bridge building). W żadnym miejscu nie postulowaliśmy idei restrukturyzacji (restructuring), która prowadziłaby do tworzenia hybryd rekonfigurujących nauki wchodzące w układ konsiliencyjny ${ }^{18}$. Interdyscyplinarność rozumianą jako starannie przemyślany eklektyzm, holistyczne i zarazem koherentne ujmowanie złożonych zjawisk społeczno-kulturowych postrzegamy jako optymalne działanie pozwalające na uzyskanie polifonicznego punktu widzenia, a jednocześnie środek do transferów i fuzji segmentów wiedzy dyscyplinarnej.

System detencji cudzoziemców w Polsce ma charakter złożony. Jednocześnie jest szczególny, wręcz unikatowy co ułatwia zakreślenie jego granic, a w ślad za tym wybór studium przypadku jako optymalnej strategii badawczej. Zastosowane podejście w pełni kwalifikuje się do miana autotelicznego (istotnego) studium przypadku albowiem przyczyną naszych zainteresowań poznawczych był przypadek (system detencyjny) sam w sobie. Szansa na realizację kompleksowych i komplementarnych badań, jaką stworzyła zgoda SG, sprawiła, że zdecydowaliśmy się na przeprowadzenie zbiorowego (wielokrotnego) studium ${ }^{19}$ wszystkich „przypadków składających się na przypadek”. Realizacja badań w sześciu ośrodkach strzeżonych w Polsce wiązała się wieloma wyzwaniami, do których trzeba zaliczyć konieczność pozyskania obszernego pakietu zasobów źródłowych, zwiększoną kosztochłonność, a także, pamiętając o limitowanym czasie na realizację badania, wysokiej próby organizację/dyscyplinę pracy zespołowej20.

Nasze zbiorowe studium przypadku wpisuje się w typ holistyczny. Rezygnacja z wyodrębniania podjednostek analizy ${ }^{21}$, jakie ma miejsce w typie zanurzeniowym, była świadomym wyborem metodologicznym, który wynikał z potrzeby globalnego ujmowania odizolowanej przestrzeni i jej kultury organizacyjnej22. Każde studium przypadku jest ukierunkowane na kompleksową analizę uwarunkowań kontekstowych

18 J.T. Klein (2010), A taxonomy of interdyscyplinarity, w: Frodeman R., Klein J.T., Mitcham C. (red.), The Oxford Handbook of Interdyscyplinarity, Oxford, s. 21

19 R.E. Stake (2009), Jakościowe studium przypadku, w: Denzin N.K., Lincoln Y.S. (red.), Metody badań jakościowych, Warszawa, tom I, s. 628-629.

20 Mieliśmy też pełną świadomość rozlicznych zagrożeń związanych z zastosowaniem tego ujęcia, zwłaszcza kwestii korespondencji między kontekstami przypadków, a w ślad za tym prawomocności integrowania ich w ramach wspólnej analizy i w związku z tym każdorazowo opracowywaliśmy raporty lokalne, zob. M.B. Miles, M.B. Huberman (2000), Analiza danych jakościowych, przeł. S. Zabielski, Białystok, s. 213. Przystępując do badania dysponowaliśmy wiedzą o zróżnicowaniu przypadków (ośrodków) wynikającym z ich profili, struktury organizacyjnej, czy infrastruktury determinującej organizację przestrzeni. Praktyka badań pokazała, że lista tych czynników jest znacznie dłuższa i obejmuje m.in. różne rozumienie misji instytucji, poziom zaangażowania i kreatywności, a także specyfikę regionalną, która oddziałuje na stabilność zatrudnienia, tryb pracy i oczekiwania personelu; szerzej o replikacji teoretycznej zob. R.K. Yin (2015), Studium przypadku w badaniach naukowych. Projektowanie i metody. Przeł. J. Gilewicz, Kraków, s. 89-94.

${ }^{21}$ Takimi potencjalnymi zanurzonymi jednostkami analitycznymi w ramach omawianego przypadku mogłyby być poszczególne sekcje lub zespoły (np. edukacyjno-wychowawcza, wartownicza), których zadania realizowane są w łatwych do wyodrębnienia, izolowanych miejscach i przestrzeniach strzeżonego ośrodka dla cudzoziemców.

22 R.K. Yin, op. cit., s. 81-82, 86-88, 94-95. 


\section{SM̂PP}

(fizycznych, społecznych, kulturowych, politycznych, etycznych, estetycznych i in.), w ramach których funkcjonuje. W sytuacji naszego projektu zbiorowego studium przypadku mamy do czynienia z sześcioma kontekstami wewnętrznymi, których rekonstrukcja jest niezbędnym warunkiem do przeprowadzenia analizy zbiorczej opartej na porównywaniu. Efekt końcowy, jakim ma być kompleksowa rekonstrukcja obrazu instytucji detencji cudzoziemców w Polsce, winien uwzględniać zarówno lokalność kontekstów, jak i ich wymiar uniwersalny, ilustrować zarówno to, co szczególne, unikatowe w wymiarze wewnętrznym, jak i w odniesieniu do świata zewnętrznego względem badanej kultury organizacyjnej.

Kolejnym elementem przyjętej strategii badań była kompleksowa triangulacja we wszystkich czterech wymiarach przedłożonych przez Normana K. Denzina ${ }^{23}$, a także systematyczna triangulacja perspektyw ${ }^{24}$.

Nasze postępowanie badawcze na poziomie triangulacji źródeł wiązało się z dwoma potrzebami. Pierwszą z nich było osiągnięcie efektu w postaci poszerzenia perspektywy oglądu badanych zjawisk. Nie chodziło tu bynajmniej o poszukiwanie i odnajdywanie identycznych wyników, lecz danych zbieżnych lub wzajemnie uzupełniających się, a także tzw. odchyleń. Każde z potencjalnych źródeł danych ma swoje silne i słabe strony, specyfikę, która pozwala na odsłanianie rzeczywistości w limitowanym zakresie. W grupie źródeł zastanych, które podzieliliśmy na kilkanaście kategorii znalazły się m.in.: akty prawne, dokumenty dotyczące przestrzeni (np. plany architektoniczne), dokumenty dotyczące organizacji miejsc i przestrzeni (np. regulaminy dnia i użytkowania przestrzeni), dokumenty dotyczące struktury organizacyjnej ośrodków oraz wykonywania obowiązków służbowych, szablony dokumentów użytkowanych w codziennej pracy ośrodków, sprawozdania i statystyki, materiały adresowane do cudzoziemców etc. ${ }^{25} \mathrm{~W}$ grupie źródeł wywołanych znalazły się m.in.: nagrania wywiadów indywidualnych ${ }^{26}$ oraz grupowych ${ }^{27}$, noty obserwacyjne zachowań i sytuacji społecznych, dzienniki badawcze, materiały zdjęciowe ${ }^{28}$.

${ }^{23}$ N.K. Denzin (1978), The Research Act. A Theoretical Introduction to Sociological Methods, New York, s. 294-302.

${ }^{24}$ U. Flick (2011), Jakość w badaniach jakościowych. Przeł. P. Tomanek, Warszawa, s. 91-128.

${ }^{25}$ Pozyskany zbiór objął kilkanaście tysięcy dokumentów.

26 Udało się zgromadzić nagrania 155 wywiadów liczące blisko 300 godzin. Obejmują one: rozmowy, niektóre kilkusesyjne, z wszystkimi osobami stanowiącymi ścisłe kierownictwo ośrodków (komendanci placówek lub naczelnicy ośrodków i ich zastępcy) - łącznie 14 wywiadów; komplet rozmów (pełna próba) z osobami będącymi kierownikami poszczególnych sekcji i zespołów - łącznie 26 wywiadów; rozmowy z większością (90\%) pracowników sekcji/zespołów oświatowo-edukacyjnych/wychowawczych - łącznie 27 wywiadów; rozmowy z pracownikami sekcji/zespołów wartowniczych (dobór celowy proporcjonalny) 39 wywiadów; rozmowy z pracownikami pozostałych sekcji/zespołów (dobór celowy proporcjonalny), a także z pracownikami technicznymi oraz osobami reprezentującymi podmioty zewnętrzne obsługujące ośrodki (dobór celowy proporcjonalny) - łącznie 49 osób.

27 Przeprowadzono sześć wywiadów grupowych z pracownikami (w których uczestniczyło 36 osób), połączonych z zastosowaniem technik projekcyjnych. W tych badaniach nie uczestniczyły osoby pełniące jakiekolwiek stanowiska kierownicze.

${ }^{28}$ Pozyskany zbiór objął kilkanaście tysięcy zdjęć, w tym materiały archiwalne udostępnione przez SG. 
Druga potrzeba związana z gromadzeniem, a następnie zestawianiem - konfrontacją źródeł polegała na ustaleniu zakresu zgodności, a z drugiej strony rozbieżności ich treści. Dobrym tego przykładem może być zagadnienie organizacji życia codziennego pensjonariuszy ośrodka detencyjnego. Ramę odniesienia informacyjnego stanowiły źródła zastane - dokumenty o charakterze regulaminów dnia, użytkowania pomieszczeń, skodyfikowanych wymogów odnośnie do zachowania cudzoziemców etc. Zawarte tam informacje konfrontowaliśmy z danymi obserwacyjnymi pozyskiwanymi podczas całodziennych pobytów studyjnych. Trzecim, dopełniającym źródłem wiedzy na omawiany temat były informacje pozyskane od personelu. Na tej drodze możliwe było zdefiniowanie relacji między „teorią" (regulacją prawno-administracyjną) a praktykami stosowanymi w badanej instytucji. Analogicznym działaniem triangulacyjnym było studiowanie dokumentów o nazwie "szczegółowy zakres obowiązków i uprawnień", które dotyczyły każdego piastowanego stanowiska, a ponadto często zawierały zróżnicowane treści w odniesieniu do konkretnej osoby. I w tym przypadku dane te porównywaliśmy z informacjami źródłowymi wygenerowanymi z obserwacji praktyk, a także rozmów z funkcjonariuszami oraz ich przełożonymi. Jeszcze innym przykładem omawianego typu triangulowania źródłowego było zestawianie planów architektonicznych ośrodków i dokumentacji inwentaryzacyjnej zawierającej opisy poszczególnych elementów przestrzeni i zakresu ich użytkowania z tym co zastaliśmy na miejscu i poddaliśmy opisowi "z natury". Warto w tym miejscu podkreślić, że przywołanych działań nie należy sprowadzać do kontroli trafności i rzetelności poszczególnych źródeł, która stanowi tylko jeden z elementów omawianego postępowania triangulacyjnego.

Kolejny postulat - triangulacja metod (metodologii) odnosi się zarówno do sposobów pozyskiwania materiałów (np. obserwowanie, rozmowa/wywiad, fokus, projekcja), jak metod ich analizy (np. metoda porównawcza, metoda dokumentarna, analiza dyskursu, brikolaż). Omówienie całego spektrum działań związanych z tym postulatem wykracza poza ramy tego tekstu i będzie zawarte we wcześniej przywołanym opracowaniu (zob. przyp. 2).

Z kolei postulat triangulacji badaczy można zaliczyć do kategorii największych wyzwań w praktyce jakościowych badań terenowych. Wiele tzw. sytuacji badawczych wyklucza możliwość równoczesnego uczestnictwa dwóch lub więcej badaczy w procedurze obserwacyjnej lub rozmowie z uczestnikiem badania. W przypadku naszego zespołowego projektu badawczego wystąpiły szczególnie sprzyjające możliwości wdrażania omawianej procedury, które wynikały ze specyfiki instytucji totalnej - organizacji przestrzeni, permanentnego monitoringu elektronicznego, zasad i standardów komunikacyjnych interakcji społecznej. Dzięki temu możliwe było przeprowadzenie symultanicznych obserwacji uczestniczących i nieuczestniczących, a także wspólnych rozmów z wybranymi kategoriami aktorów społecznych (cudzoziemcy, kierownictwo ośrodków oraz kierownicy średniego szczebla). W rezultacie udało się wygenerować szereg not obserwacyjnych dotyczących tej samej 


\section{SM̂PP}

sytuacji badawczej autorstwa różnych badaczy, wprowadzić do transkrypcji rozmów autonomiczne komentarze pochodzące od osób je przeprowadzających, zawierające m.in. indywidualne interpretacje wypowiedzi i towarzyszących im zachowań niewerbalnych.

Triangulacja teorii oznacza zestawianie ze sobą różnych teoretycznych punktów widzenia badanego zjawiska w celu oszacowania ich siły i przydatności. W klasycznym ujęciu ten typ triangulowania ma między innymi zabezpieczać projekty badawcze przed nieuzasadnionym przywiązaniem do założeń przyjętych na etapie wstępnej konceptualizacji, ignorowaniem alternatywnych interpretacji i wyjaśnień, a także zaniechaniem prób wypracowania własnej, eklektycznej koncepcji teoretycznej na bazie kolażu teorii eksponujących przydatność różnych zasobów źródłowych i metod ${ }^{29}$. W przypadku omawianego, zespołowego i interdyscyplinarnego projektu o profilu eksploracyjnym, który uwzględniał szerokie spectrum zainteresowań badaczy i stawianych pytań, a w ślad za tym perspektyw i sposobów wyjaśniania, te kwestie nabierały szczególnego znaczenia.

Bazową perspektywę teoretyczną stanowiły koncepcje przestrzeni i miejsca zaproponowane przez Marca Augé ${ }^{30}$, Michela Focaulta ${ }^{31}$ i Michela de Certeau ${ }^{32}$. W tę ramę wpisano pięć kolejnych inspiracji teoretycznych. Pierwszą z nich była klasyczna i współczesna myśl proksemiczna ${ }^{33}$ i kinezyczna ${ }^{34}$, którą staraliśmy się dopełniać ideami z zakresu antropologii zmysłów ${ }^{35}$ oraz antropologii emocjij ${ }^{36}$. Drugą inspirację stanowiła koncepcja instytucji totalnej Ervinga Goffmana, która poniekąd naturalnie wpisywała się $w$ nasz temat badawczy ${ }^{37}$. Jest ona ściśle związana z konstruktywizmem jako głównym paradygmatem w naszym podejściu badawczym i w ślad za tym kolejną inspiracją teoretyczną, jaką stanowi interakcjonizm symboliczny ${ }^{38}$. W studiach nad instytucjami/organizacjami bardzo popularne jest z różnych względów bliskie antropologom użytkowanie pojęcia kultury organizacyjnej jako metafory

${ }^{29}$ N.K. Denzin, op. cit., s. 297-300.

${ }^{30}$ M. Augé (2010), Nie-miejsca. Wprowadzenie do antropologii hipernowoczesności. Przeł. R. Chymkowski, Warszawa.

${ }^{31}$ M. Foucault (2005), Inne przestrzenie, przeł. Agnieszka Rejniak-Majewska, "Teksty Drugie”, nr 6, s. $117-125$.

32 M. de Certeau (2008), Wynaleźć codzienność. Sztuki działania. Przeł. Katarzyna Thiel-Jańczuk, Kraków.

33 Np. E.T. Hall (2001), Ukryty wymiar. Przeł. T. Hołówka, Warszawa.

${ }^{34}$ Np. A.R Dul (1995), Komunikacja niewerbalna w teorii i badaniach, w: Alina Kapciak, Leszek Korporowicz i Andrzej Tyszka (red.), Komunikacja międzykulturowa. Zbliżenia i impresje, Warszawa, s. 43-68.

35 D. Angutek (2013), Kulturowe wymiary krajobrazu. Antropologiczne studium recepcji przyrody na prowincji: od teorii do empirii, Poznań, s. 152-202. Najbardziej inspirujące na tym polu były dla nas ustalenia badaczy kanadyjskich, takich jak David Howes i Constance Classen.

${ }^{36}$ M. Rajtar, J. Straczuk (red.) (2012). Emocje w kulturze, Warszawa.

37 E. Goffman (2011), Instytucje totalne. O pacjentach szpitali psychiatrycznych i mieszkańcach innych instytucji totalnych. Przeł. O. Waśkiewicz, J. Łaszcz, Sopot.

${ }^{38}$ E. Goffman (2006). Rytuat interakcyjny. Przeł. A. Sulżycka, Warszawa; E. Goffman (2010), Analiza ramowa. Esej z organizacji doświadczenia. Przeł. S. Burdziej, Kraków. 
rdzennej-czegoś, czym organizacja jest ${ }^{39}$. Taka perspektywa, także dobrze korespondująca z koncepcją Goffmana oraz przyjętą przez nas metodyką ${ }^{40}$, stała się naszą kolejną, czwartą ramową inspiracją teoretyczną. Ostatnią z bazowych koncepcji była teoria morfogenezy Margaret Archer ${ }^{41}$. Ponadto na użytek bardziej zindywidualizowanych potrzeb członków zespołu badawczego sięgano po inne, dopełniające koncepcje teoretyczne ${ }^{42}$. Na bazie wyżej wskazanych inspiracji zbudowaliśmy model teoretyczny badania systemu detencji cudzoziemców.

Stałym elementem towarzyszącym wszystkim naszym działaniom projektowym była refleksyjność (autoetnografia) rozumiana jako akt autonarracji. Przystępując do konceptualizacji, a później realizacji naszego projektu, byliśmy w pełni świadomi naszej roli w procesie badawczym i uznaliśmy, że badacz jako narzędzie badawcze winien stać się przedmiotem analizy w takim samym stopniu, jak osoby i zjawiska znajdujące się w polu jego zainteresowań. Zamiast podejmować raczej bezproduktywne działania w celu eliminacji jego wpływu na osoby badane, proces pozyskiwania danych i ich interpretację staraliśmy skupić się na określaniu istoty tego wpływu ${ }^{43}$. Trudno w chwili obecnej wyrokować, w jakim zakresie refleksje autoetnograficzne znajdą swój wyraz w postaci pisarstwa ${ }^{44}$ - poprojektowych wypowiedziach tekstowych poszczególnych autorów. Tym bardziej nie sposób przewidzieć, w jakim stopniu będą one nawiązywały do postulatów autoetnografii ewokatywnej, a w jakim analitycznej45.

Niezwykle istotnym elementem każdego badania empirycznego jest refleksja nad etycznością podejmowanych działań. W związku z tym na gruncie większości nauk społecznych ${ }^{46}$, a także w odniesieniu do interdyscyplinarnych pól badawczych

${ }^{39}$ Np. B. Czarniawska (2010), Trochę inna teoria organizacji. Organizowanie jako konstrukcja sieci działań, Warszawa; M. Kostera (2013), Antropologia organizacji. Metodologia badań terenowych, Warszawa; Ł. Sułkowski, Cz. Sikorski (red.) (2014), Metody zarządzania kulturą organizacyjną, Warszawa.

${ }^{40}$ Mowa tu o etnografii jako najbardziej elastycznej metodzie badań jakościowych, która w całej rozciągłości korespondowała z naszym zamysłem badawczym.

${ }^{41}$ M.S. Archer (2015), Morfogeneza - ramy wyjaśniające realizmu, „Uniwersyteckie Czasopismo Socjologiczne", nr 10 (1), s. 16-46; M.S. Archer (2019), Kultura i sprawczość. Przeł. P. Tomanek, Warszawa.

${ }^{42}$ Mowa tu m.in. o koncepcji ekonomii moralności - zob. D. Fassin (2005), Compassion and Repression: The Moral Economy of Immigration Policies in France, "Cultural Anthropology", t. 20, nr 3, s. 362-387 oraz koncepcji „patron-klient” - zob. S.N. Eisenstadt, L. Roniger (1984), Patrons, Clients and Frienda. Interpersonal Relations and the Structure of Trist in Society, Cambridge.

${ }^{43}$ M. Hammersley, P. Atkinson (2000), Metody badań terenowych. Przeł. S. Dymczyk, Poznań, s. 17-18.

44 Sama "widoczność" badacza w tekście przejawiająca się m.in. w używanej formie osobowej oraz uwypuklenie aktywnej obecności "Ja” badacza w tekście należą obecnie do rudymentarnych elementów stylu pisania ludzi nauki reprezentujących wszystkie orientacje teoretyczne.

45 Zob. teksty zamieszczone W "Przegląd Socjologii Jakościowej”, tom X, nr 3: Autoetnografia technika, metoda, nowy paradygmat?; N.K. Denzin (2014), Interpretive Autoethnography, Los Angeles.

${ }^{46}$ W tekście A. Seweryn (2010: 33-51) można zapoznać się z omówieniem dwóch najważniejszych kodeksów antropologicznych wypracowanych pod koniec minionego stulecia: Ethical Guidelines for Good Research Practice (1999) - www.theasa.org/ethics.htm oraz Code of Ehics (1999) - www.aaanet.org/ committees/ethcode.htm. Z kolei J. Creswell (2013), Projektowanie badań naukowych. Metody jakościowe, ilościowe i miesznae. Przet. J. Gilewicz, Kraków, s. 107-108 przywołuje analogiczne kodeksy wypracowane przez psychologów, socjologów, pedagogów i in. 


\section{SM̂PP}

czy kategorii uczestników badań47, wypracowano kodeksy regulujące kwestie etyczne związane z przygotowywaniem i realizacją projektów badawczych, a następnie z upublicznianiem ich wyników. Nadzór nad ich przestrzeganiem sprawują zarówno instytucje macierzyste badaczy jak i podmioty finansujące projekty badawcze ${ }^{48}$. Jednocześnie badacze jakościowi są świadomi, że kwestii etyki nie da się sprowadzić do żadnego uniwersalnego zestawu reguł lub standardów, które można stosować w dowolnym kontekście empirycznym. W związku z tym mają świadomość tego, że refleksja nad moralnością i etycznością winna stanowić immanentny element pracy badawczej na każdym etapie postępowania, wymaga stałej kontroli, niejednokrotnie doraźnej rewizji i optymalizacji.

Realizowany przez nas projekt badawczy wiązał się ze szczególnymi wyzwaniami natury etycznej, albowiem przyszło nam się zmierzyć z bardzo trudnym terenem, jaki stanowią scentralizowane instytucje zamknięte o profilu hierarchicznym, kładące szczególny nacisk na dominację i podporządkowanie oraz kontrolę jako fundamentalną regułę komunikacyjną. Uwidacznia się to nie tylko w relacjach między personelem a cudzoziemcami, ale także w podgrupach, na które jest podzielony zespół pracowniczy. Na to wszystko nałożył się relatywnie wysoki status badaczy w środowisku uczestników badań, wynikający z upoważnień, jakimi dysponowali na mocy decyzji najwyższych władz Straży Granicznej ${ }^{49}$.

Sytuacja ta nie pozostawała bez wpływu na jeden z istotnych wymogów etycznych spoczywających na badaczach, jakim jest uzyskanie świadomej zgody na udział w badaniach ${ }^{50}$. Kwestia ta okazała się istotna tylko $w$ odniesieniu do personelu ${ }^{51}$,

47 International Association for the Study of Forced Migration (IASFM) Code of ethics: Critical reflections on research ethics in situations of forced migration - http://iasfm.org/wp-content/uploads/2018/11/ IASFM-Research-Code-of-Ethics-2018.pdf [data dostępu: 1.12.2019]

${ }^{48}$ W USA jest to praktyka wdrażana od kilku dekad - Y. Lincoln (2009, Komisje etyczne $i$ konserwatyzm metodologiczny. Wyzwania dla i ze strony paradygmatu fenomenologicznego. Przeł. Krzysztof Podemski, w: Norman K. Denzin i Yvonna S. Lincoln (red.), Metody badań jakościowych, Warszawa, tom 1, s. 245-279) wskazuje na szereg negatywnych zjawisk związanych ze zwiększonym nadzorem nad badaniami jakościowymi, który prowadzi do biurokratyzacji, wykluczania nowatorskich paradygmatów, epistemologii i perspektyw poznawczych, konserwowania modernistycznego modelu uprawiania nauki. Z kolei w Polsce procedury związane z prowadzeniem nadzoru etycznego są wybiórcze, komisje etyczne funkcjonują głównie w obszarze nauk przyrodniczych i medycznych, a w naukach społecznych i humanistyce zdominowane są przez psychologów i filozofów.

49 Taki stan rzeczy oraz brak wcześniejszych doświadczeń związanych z prowadzeniem badań naukowych w ośrodkach strzeżonych sprawiał, że personel początkowo postrzegał nas jako audytorów. W związku z tym przywiązywaliśmy szczególną uwagę do aranżacji badania, w tym tworzenia atmosfery zaufania, wyczerpującego informowania o naszej roli, tematyce projektu i jego celach etc.

${ }^{50}$ Hammersley i Atkinson, op. cit., s. 269-273; Creswell, op. cit., s. 109; S. Chuk i D. Latusek-Jurczak (2012), Etyka w badaniach jakościowych, w: Dariusz Jemielniak (red.), Badania jakościowe. Podejścia i teorie, tom 1, Warszawa, s. 26-32.

${ }^{51}$ Bardzo rzadko spotykaliśmy się z odmowami udziału w badaniu, jednak nie oznacza to, że personel nie miał wątpliwości, czy wręcz obaw związanych z prowadzeniem rozmów z nami, które często postrzegał jako jeden z obowiązków służbowych wykonywanych w czasie pracy. Jednak wraz z upływem czasu badań, po uzyskaniu od pierwszych rozmówców informacji o tematyce rozmów i ich atmosferze, 
a nie dotyczyła samych cudzoziemców. Z zasady do rozmów z nimi nie dochodziło z inicjatywy samych badaczy, nie opierały się na ukierunkowanych dyspozycjach badawczych, nie były też rejestrowane na dyktafonie. Rozmowy te miały zazwyczaj charakter towarzyskich pogawędek prowadzonych w miejscach rekreacyjnych lub palarniach. Na pytania cudzoziemców o cel naszej obecności i wykonywaną profesję udzielaliśmy wyczerpujących informacjij ${ }^{52}$.

Drugą, z najczęściej wskazywanych dyrektyw dotyczących etyczności badań, jest gwarancja anonimowości uczestnikom badań, a w ślad za tym zapobieżenia potencjalnej szkodliwości wynikającej z kontaktu z badaczami. Przystępując do wywiadów z personelem gwarantowaliśmy poufność uzyskanych informacji, w tym ich przetworzenie uniemożliwiające identyfikację treści z rozmówcą, a nawet z ośrodkiem, w którym jest zatrudniony. Każdorazowo prosiliśmy o wyrażenie zgody na nagrywania i szczegółowo opisywaliśmy nasze procedury związane z użytkowaniem tego materiału źródłowego ${ }^{53}$. Zdarzało się, że rozmówca wyrażał życzenie przerwania, gdy chciał przekazać jakieś informacje dotyczące jego życia prywatnego lub opinii o środowisku zawodowym.

Trzecią, często podnoszoną w dyskusjach metodologicznych kwestią, która wymaga wyjaśnienia w odniesieniu do naszych badań, jest nieetyczność prowadzenia ukrytej obserwacji nieuczestniczącej (ekstraspekcyjnej). W warunkach badanej instytucji zamkniętej stały monitoring większości jej przestrzeni wyposażonej zwykle w kilkadziesiąt kamer (poza pokojami mieszkalnymi, łazienkami i ubikacjami) jest rudymentarnym zajęciem służb wartowniczych dysponujących zestawem monitorów w swoich pomieszczeniach ${ }^{54}$. Cudzoziemcy są w pełni świadomi takiego stanu rzeczy i do niego przyzwyczajeni. Analogiczna sytuacja ma miejsce w przypadku prowadzenia bezpośredniej, ale w pełni jawnej obserwacji nieuczestniczącej w takich miejscach jak np. otwarty plac do zajęć sportowo-rekreacyjnych. W związku z tym uznaliśmy, iż nasze prace związane z wykorzystaniem omawianej techniki badawczej w tak specyficznie zorganizowanej przestrzeni instytucjonalnej nie są obciążane znamionami czynności o charakterze działania niemoralnego. Trzeba jednak wyraźnie zaznaczyć, że taka

nastawienie personelu do spotkań z nami uległo znaczącej zmianie. W szeregu przypadków udawało się nam nawiązać relacje nieformalne i prowadzić rozmowy, które były traktowane jako wręcz towarzyskie.

52 Niemniej cudzoziemcy chyba nadal nie pozbywali się wątpliwości co do rzeczywistego celu naszego pobytu w ośrodkach. Świadczą o tym m.in. próby podejmowania przez nich rozmów, w których prosili nas o interwencję, o pomoc w rozwiązaniu różnego rodzaju problemów, z którymi borykają się jako osoby umieszczone w zamkniętych ośrodkach.

53 Nagrania były transkrybowane przez samych badaczy oraz zaufanego współpracownika, a następnie utylizowane. Z kolei transkrypcje anonimizowano poprzez zakodowanie i usuwanie treści umożliwiających identyfikację rozmówcy, a następnie deponowane w jednym miejscu, do którego dostęp mają jedynie badacze -na specjalnie zabezpieczonej chmurze administrowanej przez UJ. Analogiczne procedury, kodowanie i inne czynności związane z anonimizacją oraz przechowywanie, przeprowadzono w odniesieniu do not obserwacyjnych, materiałów ikonograficznych i innych źródeł.

${ }^{54}$ Podobnie wygląda sytuacja z niektórymi pomieszczeniami wartowników wyposażonymi w lustra weneckie z widokiem na korytarze lub sale komputerowe. 


\section{SM̂PP}

obserwacja nie wiązała się z pozyskiwaniem zapisów, a jedynie oglądem na żywo i sporządzaniem not. Głównym celem tego typu obserwowania było uchwycenie częstotliwości przemieszczania się pomiędzy poszczególnymi miejscami w ośrodku i ustalenie, które pomieszczenia są najczęściej użytkowane bądź pomijane.

$Z$ kolei realizowane przez nas obserwacje uczestniczące $w$ miejscach publicznych nie wiązały się z nadużyciem praw osób obserwowanych do prywatności, z nieprawdziwą prezentacją celu badania, czy też budowaniem tzw. fałszywej tożsamości w celu uzyskania dostępu do obserwowanej sytuacji55.

Opisując powyższe działania nie staraliśmy się przekonać czytelnika, że żywimy się iluzorycznym przekonaniem co do roli refleksji etycznej jako skutecznego remedium na w pełni skuteczną optymalizację relacji z uczestnikami badań. Relacje te były swego rodzaju grą, gdzie występowaliśmy jako jedni z aktorów społecznych, których cele i wynikające z nich zadania oraz zastosowane środki często nie korespondowały z wyobrażeniami i oczekiwaniami drugiej strony, bywały dla niej niezrozumiałe. Model badań niebudzący żadnych wątpliwości etycznych, w którym badacz występuje w roli w pełni empatycznego, przyjacielskiego i transparentnego partnera uczestnika badań jest w praktyce niemożliwy do urzeczywistnienia. Obecnie zespół badawczy prowadzi dyskusje nad postacią upubliczniania wyników w materiałach publikowanych i podczas wystąpień konferencyjnych. Narady te, uwzględniające m.in. profil odbiorców i potencjalne konsekwencje dla wszystkich stron, zawsze obejmują rozliczne aspekty natury moralno-etycznej ${ }^{56}$.

\section{Bibliografia}

Angrosino M. (2010), Badania etnograficzne i obserwacyjne. Przeł. Maja Brzozowska-Brywczyńska, Warszawa: Wydawnictwo Naukowe PWN.

Angutek D. (2013), Kulturowe wymiary krajobrazu. Antropologiczne studium recepcji przyrody na prowincji: od teorii do empirii, Poznań: Bogucki Wydawnictwo Naukowe.

Archer M.S. (2015), Morfogeneza - ramy wyjaśniające realizmu, „Uniwersyteckie Czasopismo Socjologiczne", nr 10 (1), s. 16-46.

Archer M.S. (2019), Kultura i sprawczość. Przeł. P. Tomanek, Warszawa: Narodowe Centrum Kultury. Augé M. (2010), Nie-miejsca. Wprowadzenie do antropologii hipernowoczesności. Przeł. R. Chymkowski, Warszawa: Wydawnictwo Naukowe PWN.

Białas J., Klaus W. (red.) (2014), Wciąż za kratami. Raport z monitoringu strzeżonych ośrodków dla cudzoziemców przeprowadzony przez Helsińską Fundację Praw Człowieka oraz Stowarzyszenie Interwencji Prawnej. Warszawa: HFPC i SIP. https://interwencjaprawna.pl/wp-content/ uploads/wciaz-za-kratami.pdf [data dostępu: 15.12.2019]

${ }_{55}$ M. Angrosino (2010), Badania etnograficzne i obserwacyjne. Przeł. Maja Brzozowska-Brywczyńska, Warszawa, s. 121-125.

${ }^{56}$ D. Silverman (2008), Interpretacja danych jakościowych. Metody analizy rozmowy, tekstu i interakcji, przeł. Małgorzata Głowacka-Grajper i Joanna Ostrowska, Warszawa, s. 289-292; Creswell, op. cit., s. $107-112$. 
Bosworth M. (2014), Inside Migration Detention, Oxford: University Press.

Brudzińska J. (2014), Horyzontalna a wertykalna struktura interdyscyplinarności. Spojrzenie fenomenologiczne, w: Kurczewska J., Lejzerowicz M. (red.), Głosy w sprawie interdyscyplinarności. Socjologowie, filozofowie i inni o pojęciach, podejściach i swych doświadczeniach, Warszawa: Wydawnictwo IFiS PAN, s. 251-255.

Certeau M. de, (2008), Wynaleźć codzienność. Sztuki działania. Przeł. Katarzyna Thiel-Jańczuk, Kraków: Wydawnictwo Uniwersytetu Jagiellońskiego.

Chuk S. i Latusek-Jurczak D. (2012), Etyka w badaniach jakościowych, w: Dariusz Jemielniak (red.), Badania jakościowe. Podejścia i teorie, tom 1, Warszawa: PWN, s. 23-40.

Creswell John W. (2013), Projektowanie badań naukowych. Metody jakościowe, ilościowe i mieszane, przeł. Joanna Gilewicz, Kraków: Wydawnictwo Uniwersytetu Jagiellońskiego.

Czarniawska B. (2010), Trochę inna teoria organizacji. Organizowanie jako konstrukcja sieci dziatań, Warszawa: Wydawnictwo Poltext.

Denzin N.K. (1978), The Research Act. A Theoretical Introduction to Sociological Methods, New York: Mc Graw-Hill.

Denzin N.K. (2014), Interpretive Autoethnography, Los Angeles: Sage.

Eisenstadt S.N., Roniger L. (1984), Patrons, Clients and Friends. Interpersonal Relations and the Structure of Trust in Society, Cambridge: University Press.

Dul A.R. (1995), Komunikacja niewerbalna w teorii i badaniach, w: Alina Kapciak, Leszek Korporowicz i Andrzej Tyszka (red.), Komunikacja międzykulturowa. Zbliżenia i impresje, Warszawa, s. $43-68$.

Fassin D. (2005), Compassion and Repression: The Moral Economy of Immigration Policies in France, "Cultural Anthropology”, t. 20, nr 3, s. 362-387.

Flick U. (2011), Jakość w badaniach jakościowych. Przeł. P. Tomanek, Warszawa: Wydawnictwo Naukowe PWN.

Flynn M.J. i Flynn M.B. (red.) (2017), Challenging Immigration Detention: Academics, Activists and Policy-makers, Cheltenham: Edward Elgar.

Foucault M. (2005), Inne przestrzenie, przeł. Agnieszka Rejniak-Majewska, „Teksty Drugie”, nr 6, s. $117-125$.

Goffman E. (2011), Instytucje totalne. O pacjentach szpitali psychiatrycznych i mieszkańcach innych instytucji totalnych. Przeł. O. Waśkiewicz, J. Łaszcz, Sopot: Gdańskie Wydawnictwo Psychologiczne.

Goffman E. (2006). Rytuał interakcyjny. Przeł. A. Sulżycka, Warszawa: Wydawnictwo Naukowe PWN.

Goffman E. (2010), Analiza ramowa. Esej z organizacji doświadczenia. Przeł. S. Burdziej, Kraków: Zakład Wydawniczy NOMOS.

Hall E.T. (2001), Ukryty wymiar, przeł. T. Hołówka, Warszawa: Wydawnictwo Literackie MUZA SA. Hammersley M., Atkinson P. (2000), Metody badań terenowych. Przeł. S. Dymczyk, Poznań: Zysk i Spółka.

International Association for the Study of Forced Migration (IASFM) Code of ethics: Critical reflections on research ethics in situations of forced migration - http://iasfm.org/wp-content/ uploads/2018/11/IASFM-Research-Code-of-Ethics-2018.pdf

[data dostępu: 1.12.2019]

Jankowska P. (2017), Detencja cudzoziemców w Polsce - granice konfliktu interesów. „Internetowy Przegląd Prawniczy TBSP UJ", nr 4, s. 152-162. 


\section{SM̂PP}

Klaus W., Rusiłowicz K. (red.) (2012), Migracja to nie zbrodnia. Raport z monitoringu strzeżonych ośrodków dla cudzoziemców, Warszawa: SIP. https://interwencjaprawna.pl/wp-content/uploads/monitoring_osrodkow_strzezonych_2012.pdf [data dostępu: 15.12.2019]

Klein J.T. (2010), A taxonomy of interdyscyplinarity, w: Frodeman R., Klein J.T., Mitcham C. (red.), The Oxford Handbook of Interdyscyplinarity, Oxford: University Press, s. 15-30.

Kostera M. (2013), Antropologia organizacji. Metodologia badań terenowych, Warszawa: Wydawnictwo Naukowe UAM.

Kurczewska J. (2014), Autorytet i interdyscyplinarność, w: J. Kurczewska, M. Lejzerowicz (red.), Głosy w sprawie interdyscyplinarności. Socjologowie, filozofowie i inni o pojęciach, podejściach i swych doświadczeniach, Warszawa: Wydawnictwo IFiS PAN, s. 273-288.

Labanca N., Ceccorulli M. (2014), Introduction, in: Ceccorulli M., Labanca N. (red.), The EU, Migration and the Politics of Administrative Detention, London-New York: Routledge, s. 1-19.

Lincoln Y.S. (2009), Komisje etyczne $i$ konserwatyzm metodologiczny. Wyzwania dla i ze strony paradygmatu fenomenologicznego. Przeł. K. Podemski, w: Norman K. Denzin i Yvonna S. Lincoln (red.), Metody badań jakościowych, Warszawa: Wydawnictwo Naukowe PWN, tom 1, s. $245-279$.

Migreurop (2013), Detention of Migrants. The favourite means of migration „management”. „Migreurop brief", nr 2, s. 1-2. http://www.migreurop.org/IMG/pdf/Note_de_MIGREUROP_detention_EN_Web.pdf [data dostępu: 15.12.2019]

Miles M.B., Huberman A.M. (2000), Analiza danych jakościowych. Przeł. S. Zabielski, Białystok: Wydawnictwo Uniwersyteckie Trans Humana.

„Przegląd Socjologii Jakościowej” (2014), tom X, nr 3: Autoetnografia - technika, metoda, nowy paradygmat?

Rajtar M., Straczuk J. (red.) (2012), Emocje w kulturze, Warszawa: Wydawnictwo Uniwersytetu Warszawskiego.

Ryan B., Mitsilegas V. (red.) (2010), Extrateritorial Imigration Control. Legal Challenges, Leiden-Boston: Martinus Nihof Publishers.

Rafalik N. (2012), Cudzoziemcy ubiegający się o nadanie statusu uchodźcy w Polsce - teoria a rzeczywistość (praktyka) (stan prawny na dzień 31 grudnia 2011 r.), CMR Working Papers, No. 55/113.

Seweryn A. (2010), Kodeks etyczny antropologa, w: Katarzyna Kaniowska, Noemi Modnicka (red.), Etyczne problemy badań antropologicznych, Wrocław-Łódź: Polskie Towarzystwo Ludoznawcze, s. 33-51.

Sieniow T. (2016), Stosowanie alternatyw do detencji cudzoziemców w Polsce w latach 2014-2015. Raport z monitoringu, Lublin: Instytut na Rzecz Prawa.

Stake R.E. (2009), Jakościowe studium przypadku, w: Denzin N.K., Lincoln Y.S. (red.). Metody badań jakościowych, Warszawa: Wydawnictwo Naukowe PWN, tom I, s. 623-654.

Silverman D. (2008), Interpretacja danych jakościowych. Metody analizy rozmowy, tekstu i interakcji, przeł. Małgorzata Głowacka-Grajper i Joanna Ostrowska, Warszawa: Wydawnictwo Naukowe PWN.

Silverman S.J., Massa E. (2012), Why Immigration Detention is Unique. "Population, Space and Place", 18: 677-686.

Stanowisko Komitetu Badań nad Migracjami PAN w sprawie dokumentu „Polityka migracyjna Polski" (10 czerwca 2019 r., 70 stron) http://www.kbnm.pan.pl/images/Stanowisko_KBnM_Polska_polityka_migracyjna_03072019.pdf [data dostępu: 15.12.2019] 
Sułkowski Ł., Sikorski Cz. (red.) (2014), Metody zarządzania kulturą organizacyjną, Warszawa: Difin SA.

Ustawa z dnia 12 grudnia 2013 r. o Cudzoziemcach. Dz.U. 2013, poz. 1650.

Yin R.K. (2015), Studium przypadku w badaniach naukowych. Projektowanie i metody. Przeł. J. Gilewicz, Kraków: Wydawnictwo Uniwersytetu Jagiellońskiego.

Wilsher D. (2014), Immigration Detention. Law, History, Politics. Cambridge: Univeristy Press.

Założenia Polityki Migracyjnej Polski (2019), Red: Zespół do spraw Migracji. Departament Analiz i Polityki Migracyjnej MSWiA. https://interwencjaprawna.pl/wp-content/uploads/2019/06/ Polityka-migracyjna-Polski-wersja-ostateczna.pdf [data dostępu: 15.12.2019] 